\section{Good neighbours}

\section{A tight-knit community and a cooperative spirit has helped San Diego to} succeed. Eric Niiler checks out California's rising star.

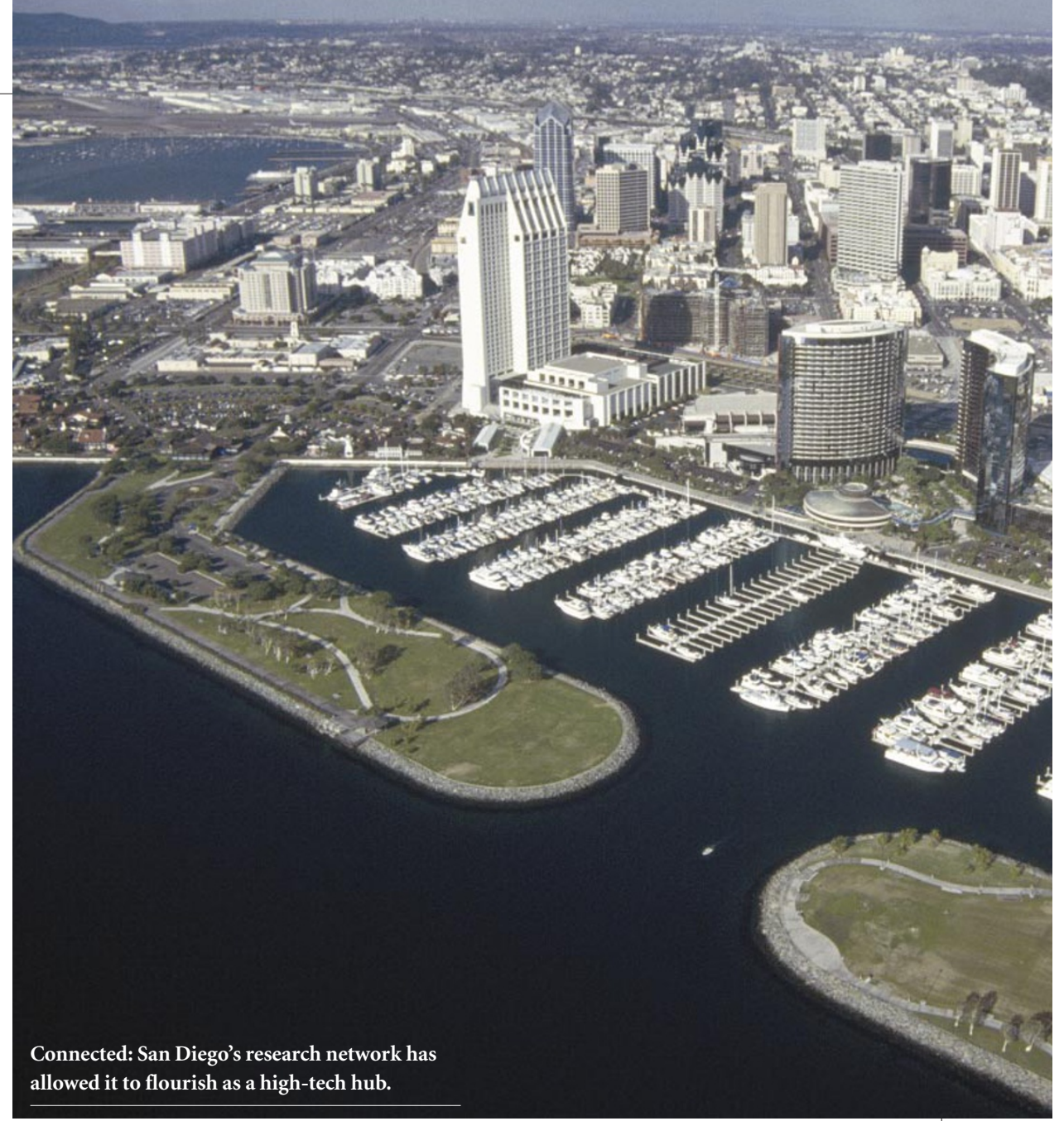

some technology firms are beginning to look elsewhere to build their new facilities. But with a high influx of federal funds, the region looks unlikely to relinquish its status just yet.

High-technology and biotechnology clusters don't grow overnight. Each follows its own long-term formula for success, usually backed by the presence of outstanding universities, a healthy flow of government research money, and venture capitalists prepared to fund start-up firms.

The cluster in San Diego is no exception, although its rapid rise has attracted the attention of scientists, entrepreneurs and policy-makers worldwide, who are keen to emulate its success in their own cities.

\section{Strength in diversity}

Today, one in eight San Diego workers is employed in the technology cluster, a broad category that includes the biotechnology, life-science and medical-device sectors, telecommunications and electronics firms, computer companies and military-related tech firms. In 2003, San Diego biotech companies reported a collective $\$ 1.8$ billion in revenue and had nearly 200 products in development, according to BIOCOM, the local biotech industry organization.

San Diego began its transformation from a tourist and military town into one of the world's most innovative high-tech regions after a crippling recession in the early 1990s, which hit as a result of cuts in US military spending as the cold war dwindled. This led to the loss of some 60,000 jobs, but the region has managed to avoid the massive job losses in other areas during the more recent tech decline. Many other tech-dependent regions — such as the San Francisco Bay Area - continue to suffer economic headaches following the collapse of the dotcom bubble in 2001-02. Despite contractions in some fields — notably telecoms - overall employment in San Diego's tech sector has risen steadily from 99,377 in 1995 to 162,251 this year, according to Alexander X, a publisher based in San Diego that tracks such employment in California (see chart, opposite). It achieved this partly by balancing biotech with hightech - the wireless, software and telecoms sectors have seen reduced profits over the past two years, but biotech has grown.

Another factor is that San Diego-based companies and universities have received $\$ 1.4$ billion in new defence research and development contracts since 2001 for counter-terrorism R\&D. High-tech communications software and biodefence research are now priorities for the US government. Fortunately for San Diego, which suffered significant job losses in the defence sector in 


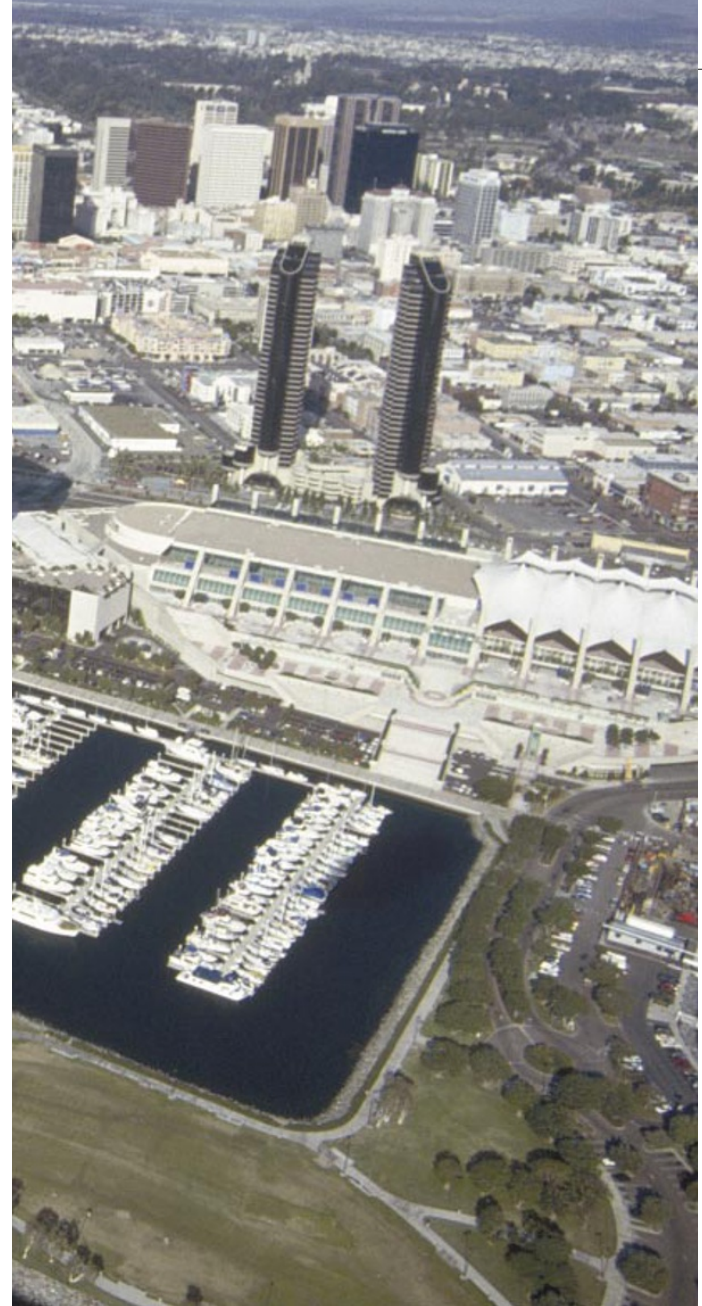

the early 1990s, it already had the infrastructure in place to meet the new challenges. "We've been saved because of our diversity," says Kelly Cunningham, an economist and research director at the San Diego Regional Chamber of Commerce.

\section{Biotech boost}

Nowhere is San Diego's resurgence more obvious than in biotechnology. The city designated the 50-square-kilometre Torrey Mesa region as a zone for research and industry in the early 1960s, and since the first biotech firms were set up in the late 1980s, dozens of academic scientists have taken their ideas to nearby technology companies or started up their own.

Since 1990, for example, UCSD has produced 69 biotech and high-tech firms, which currently earn the school $\$ 17$ million per year in licensing fees. The Salk Institute has launched 17 companies since the late 1980s, and researchers at Scripps - one of the largest non-profit research institutes in the United States - have developed 40 companies over a similar period of time.

Despite its rapid growth, many inhabitants maintain that San Diego still feels like a small town, living in the shadow of Los Angeles two hours' drive to the north. It is off the beaten track, which means that researchers and business people feel that they must share ideas and sometimes even office space.

BIOCOM has been important for promoting such informal networking. This has been particularly true for young tech entrepreneurs looking for experienced mentors who have already gone through the boomand-bust cycles of the technology industry, says Bob Slapin, executive director of the San Diego Software Industry Council.

"The biggest difference between San Diego and other regions is a support structure and experienced individuals who are willing to assist companies," Slapin says. BIOCOM, for example, has set up joint purchasing contracts with a variety of suppliers so that a group of small biotech firms can save money by making bulk orders of specialized equipment or services such as compressed gas, lab equipment, insurance and cleaning services.

Networking and informal get-togethers have also led to a 'cross-pollinization' of new technologies. For example, a blend of genomics and computational modelling has led to the evolution of several hybrid firms. Cengent Therapeutics is using three-dimensional technology originally designed to spot military targets to identify possible drug-delivery locations. "These are crossover technologies that lead from software to biology," says Fred Cutler, former head of UCSD CONNECT, an arm of the university that helps to develop and foster start-up technology firms.

Such opportunities have also proved attractive to the pharmaceutical industry. Several big drug firms have expanded their research divisions into San Diego because of

Who works where: the number of employees across San Diego's technology sector in 2003.

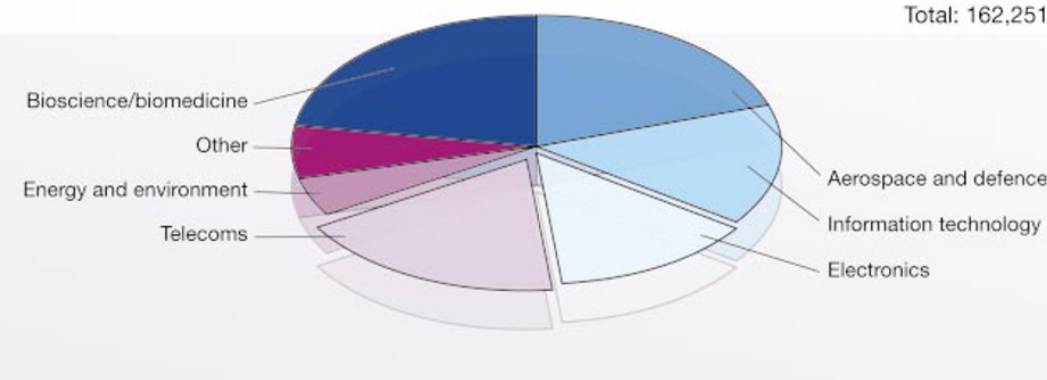

the cluster of biotech talent hat exists there. Pfizer opened a new 70,000-square-metre research centre in May 2002 to study AIDS, diabetes and cancer. Novartis, Johnson \& Johnson, Merck and Elan have all established West Coast research hubs in San Diego in recent years, providing more jobs in the area.

\section{Cash rich}

But if networking and cross-fertilization are driving San Diego's success, then oiling the wheels is the high level of funding available to the region. In 2002, San Diego's entire technology sector received $\$ 1$ billion in private venture-capital funding. And in a report by the Brookings Institution, the city - along with Raleigh-Durham and Seattle, two other successful biotech clusters - was identified as receiving an average of $\$ 500$ million annually from the National Institutes of Health (NIH) during 1990-2000 and at least $\$ 700$ million in private venturecapital funds from 1994-2001.

San Diego's success at attracting such high levels of funding can largely be attributed to its proactive approach. UCSD CONNECT, for example, was set up in 1995 to help start-up companies obtain financial back-up. It has subsequently initiated a series of scientist-to-business forums that to date have helped technology companies raise more than $\$ 5.8$ billion. The various institutions in the region agree that their active solicitation of ideas from their own faculty members has also helped to bring money into the area.

"We try to make them understand that their duty is to do more than just make a 


\section{Biotech and high-tech hubs}

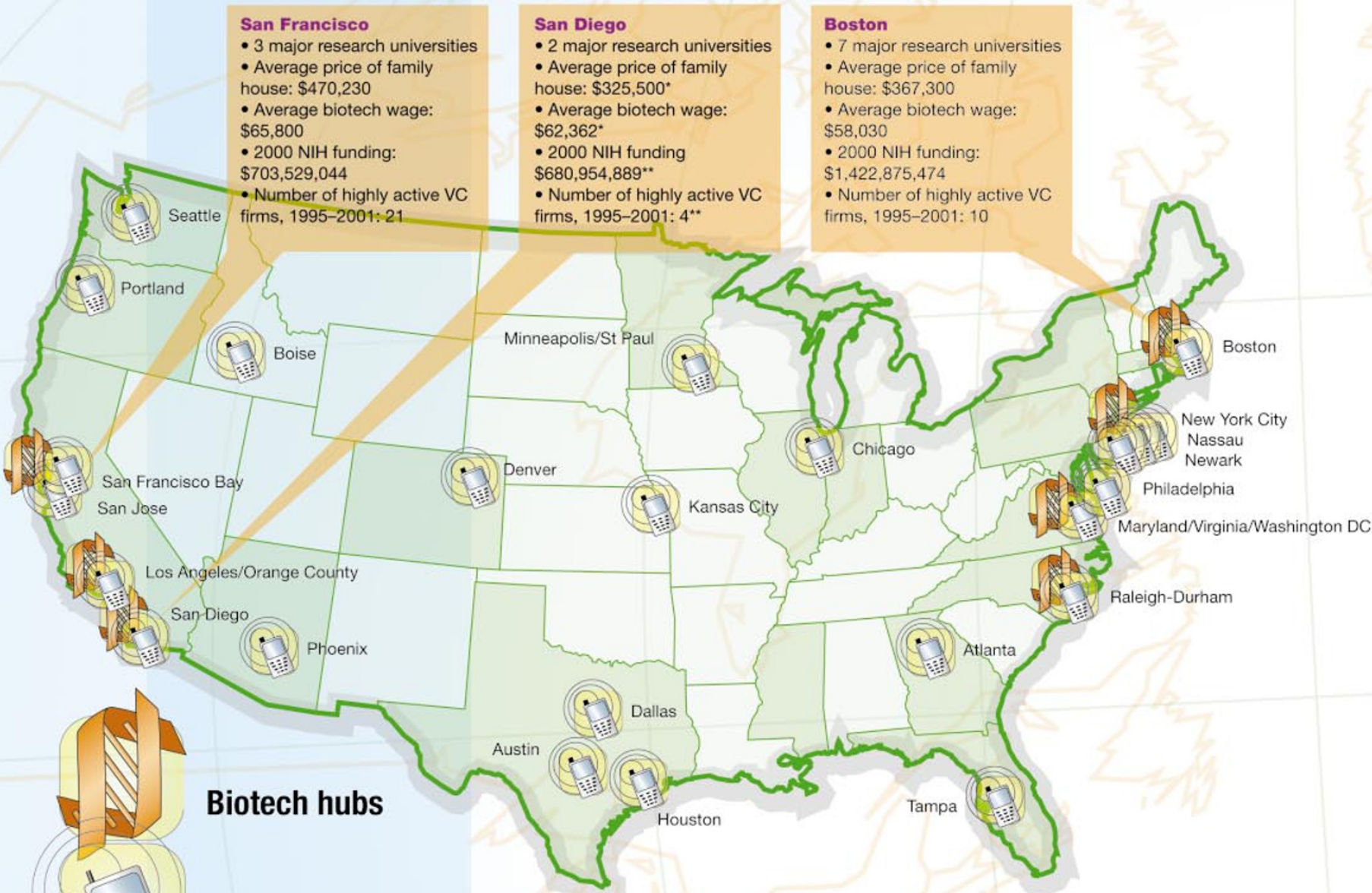

\section{$==\quad$ High-tech hubs}

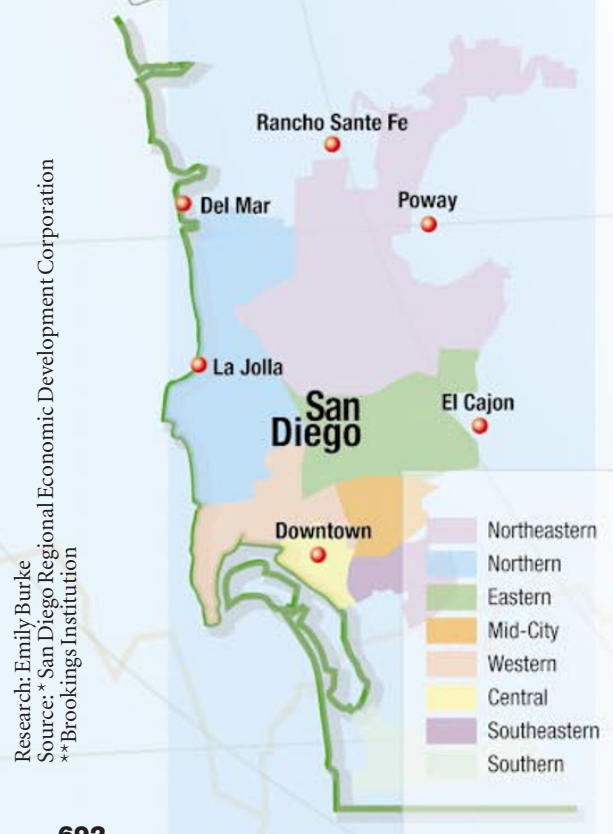

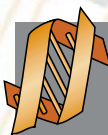

San Francisco Bay Area Boston Area San Diego New York/New Jersey Raleigh-Durham Los Angeles/Orange County Maryland, Virginia, Washington Source: *

\section{Institutions and associations in San Diego}

- Institutes

Burnham Institute

California Institute for Telecommunications and Information Technology

Jacobs School of Engineering, UCSD

La Jolla Institute for Allergy and Immunology

School of Medicine, UCSD

The Neurosciences Institute

Salk Institute for Biological Studies

San Diego State University

San Diego State University Graduate School of Business

San Diego Supercomputer Center at UCSD

Scripps Clinic
Scripps Foundation for Medicine and Science

Scripps Institution of Oceanography

Sidney Kimmel Cancer Center

The Scripps Research Institute

University California, San Diego

University of San Diego

- Associations

BIOCOM

California Healthcare Institute

San Diego Regional Chamber of Commerce

San Diego Regional Economic Development Corporation

San Diego Telecom Council

UCSD CONNECT 


\begin{tabular}{|c|c|c|c|c|c|c|c|}
\hline & \multicolumn{7}{|c|}{ Number of employees, 2003 (thousands) } \\
\hline$=$ & $\begin{array}{l}\text { Wireless } \\
\text { telecom }\end{array}$ & Telecom & $\begin{array}{l}\text { Internet service } \\
\text { provision }\end{array}$ & $\begin{array}{l}\text { Computer and } \\
\text { electronics } \\
\text { manufacturing }\end{array}$ & $\begin{array}{l}\text { Communications } \\
\text { equipment } \\
\text { manufacturing }\end{array}$ & $\begin{array}{l}\text { Semiconductor } \\
\text { manufacturing }\end{array}$ & $\begin{array}{c}\text { Total } \\
\text { employment }\end{array}$ \\
\hline San Jose, California & - & - & 9.3 & 124 & - & 56.3 & 189.6 \\
\hline Los Angeles/Orange County & 3.4 & 45.2 & 11.1 & 99.6 & 3.4 & 15.1 & 177.8 \\
\hline Dallas, Texas & - & 39.8 & 17.6 & 50.2 & 11.5 & 25.7 & 144.8 \\
\hline $\begin{array}{l}\text { Maryland, Northern Virginia, } \\
\text { Washington DC }\end{array}$ & 3.6 & 59 & 22.3 & 18.9 & - & - & 103.8 \\
\hline Chicago, Illinois & - & 36.8 & 15.5 & 37.7 & - & - & 90.0 \\
\hline Boston Area & - & 15.4 & - & 48.9 & 5.2 & 11.3 & 80.8 \\
\hline San Diego & 7.4 & 15 & 14.5 & 25.5 & 5.2 & - & 67.6 \\
\hline Portland, Oregon & - & - & - & 34.5 & - & 25.3 & 59.8 \\
\hline Philadelphia, Pennsylvania & - & 20.2 & 12.9 & 25.8 & - & - & 58.9 \\
\hline Atlanta, Georgia & 13.4 & 44.6 & - & - & - & - & 58.0 \\
\hline Phoenix, Arizona & - & 17.2 & - & 38.5 & - & - & 55.7 \\
\hline Minneapolis/St Paul, Minnesota & - & - & 9.2 & 38.9 & - & - & 48.1 \\
\hline Austin, Texas & - & - & - & 30.9 & - & 16.7 & 47.6 \\
\hline Seattle, Washington & 10.3 & 18.8 & - & 15.7 & - & - & 44.8 \\
\hline San Francisco Bay Area & - & 14.2 & 7.5 & 22.9 & - & - & 44.6 \\
\hline Houston, Texas & - & 15.4 & - & 18.7 & - & - & 34.1 \\
\hline Tampa, Florida & - & 15.8 & 5.3 & - & 3.4 & 3.8 & 28.3 \\
\hline New York City & - & 26.2 & - & - & - & - & 26.2 \\
\hline Kansas City & - & 25.8 & - & - & - & - & 25.8 \\
\hline Denver, Colorado & - & 25.8 & - & - & - & - & 25.8 \\
\hline Raleigh-Durham, North Carolina & - & - & - & 25.2 & - & - & 25.2 \\
\hline Boise, Idaho & - & - & - & 14.5 & - & 9.8 & 24.3 \\
\hline Nassau, New York & - & - & - & 17.8 & - & 4.4 & 22.2 \\
\hline Newark, New Jersey & - & 13.5 & - & - & - & - & 13.5 \\
\hline
\end{tabular}

\section{High-tech}

\section{world view}

\begin{tabular}{lrc}
\hline Country & $\begin{array}{r}\text { R\&D expenditure, } \\
\text { USS billion* }\end{array}$ & $\begin{array}{r}\text { Number of patents } \\
\text { filed, 1998 }\end{array}$ \\
\hline United States & 282.3 & 14,401 \\
\hline Japan & 103.8 & 10,230 \\
China (excluding Hong Kong) & 58.8 & - \\
\hline Germany & 53.9 & 5,736 \\
\hline France & 35.1 & 2,044 \\
\hline United Kingdom & 29.4 & 1,851 \\
\hline Korea & 22.3 & 355 \\
\hline India & 19.4 & - \\
\hline Canada & 17.4 & 511 \\
\hline Italy & 15.5 & 713 \\
\hline Brazil & 13.7 & - \\
\hline Russian Federation & 11.6 & - \\
\hline Chinese Taipai & 10.9 & - \\
\hline Sweden & 9.9 & 951 \\
\hline Netherlands & 8.4 & 782 \\
\hline Spain & 8.2 & 105 \\
\hline Australia & 7.7 & 271 \\
\hline Israel & 6.4 & - \\
\hline Switzerland & 5.6 & 848 \\
\hline Belgium & 4.9 & 380 \\
\hline Finland & 4.7 & 386 \\
\hline Austria & 4.4 & 260 \\
\hline Mexico & 3.5 & 12 \\
\hline Denmark & 3.2 & 220 \\
& & \\
\hline
\end{tabular}

\begin{tabular}{lcc|}
\hline Country & $\begin{array}{r}\text { R\&D expenditure, } \\
\text { US\$ billion* }\end{array}$ & $\begin{array}{c}\text { Number of patents } \\
\text { filed, } 1998\end{array}$ \\
\hline Norway & 2.7 & 117 \\
Turkey & 2.7 & 4 \\
Poland & 2.6 & 10 \\
\hline South Africa & 2.6 & - \\
Czech Republic & 2.0 & 10 \\
Singapore & 2.0 & - \\
\hline Argentina & 1.9 & - \\
\hline Portugal & 1.5 & 6 \\
\hline Ireland & 1.4 & 43 \\
\hline Hungary & 1.3 & 24 \\
\hline Greece & 1.1 & 11 \\
\hline Hong Kong & 1.0 & - \\
\hline Chile & 0.9 & - \\
New Zealand & 0.8 & 37 \\
\hline Slovenia & 0.6 & - \\
\hline Romania & 0.5 & - \\
\hline Slovak Republic & 0.4 & 5 \\
\hline Iceland & 0.3 & 11 \\
\hline Bulgaria & 0.3 & - \\
\hline Lithuania & 0.2 & - \\
\hline Estonia & 0.1 & - \\
\hline Latvia & 0.1 & - \\
\hline Cyprus & 0.04 & - \\
\hline Source: 0 OECD; *2001 or latest available year & \\
\hline & & \\
\hline
\end{tabular}

discovery and publish a paper," says Alan Paau, assistant vice-chancellor at UCSD and director of the school's technology-transfer programme.

Although San Diego produces a large number of science graduates, helping to fuel its culture of innovation, relatively few of them have the business and administration experience needed to manage and expand technology firms. To help meet this need, UCSD will open a graduate business school in 2004, and has already begun a dual major PhD/MBA programme with San Diego State University. This programme allows molecular-biology students to earn a business degree at the same time as working for their main degree.

Junfu Zhang, a research fellow at the Public Policy Institute of California, says that entrepreneurs who can understand both business and science - such as those graduating from a dual programme - are more likely to succeed than those following a more traditional degree path. Zhang has studied California's high-tech industry and found that $40 \%$ of venture-backed entrepreneurs came from a university setting. "You can never overestimate the role played by universities in developing entrepreneurship," he says.

\section{Saturation point}

Nevertheless, industry executives and other experts are warning that San Diego's technology cluster is facing some immediate challenges. At $50 \%$ above the national average, house prices are very high compared with wages, commuting times are increasing and the area is running out of land that can be developed. City of San Diego councillor Scott Peters admits that the region could soon become a victim of its own success. "It's getting a little crowded," he says.

This crowding was painfully clear during October, when wildfires spread from house to house, destroying 2,400 homes and killing 16 people in San Diego County. Fortunately for the region's tech development, no research centre was destroyed and most analysts believe that there will not be a long-term economic effect.

Despite the damage caused by the fires in rural San Diego, the most pressing issue is the long-term provision of housing. Currently, only one in five San Diego families can afford the average house price of about $\$ 380,000$ (\$490,000 for new homes). Many young families moving to the area are forced to seek out cheaper housing in areas north and east of the city, such as Riverside county, about 60 minutes away by car. The housing 
situation is so bad that the city council declared a 'housing emergency' in 2003, and is looking for innovative ways to encourage developers to build more housing that is affordable to low- and middleincome earners.

"It's a market issue," says Peters, "and probably bigger than we can do locally. We do have to find a way to make investment in housing more attractive to private capital." One possibility, Peters says, is to require suburban developers to include in their plots a certain number of housing units that are affordable to low- and middle-income residents, although builders are distinctly uneasy about this proposal.

Another problem is the lack of water in the region. San Diego imports $80 \%$ of its water from the Colorado River 200 kilometres to the east. But the federal government has ordered California to reduce its use of the river by $20 \%$ over the next decade. San Diego officials are looking at alternatives such as desalination and recycling. Already, firms such as Ligand Pharmaceuticals, a biotech firm based in San Diego, are using reclaimed water in their manufacturing, but the price of water is likely to add to the cost of doing business in San Diego. As a state, California is taking an increased amount of water from agricultural regions to sell to the cities. So far, it is not clear how the cost structure will pan out, although analysts agree that the price of water is going to go up.

The amount of land left to build on is shrinking, and the vaunted Torrey Mesa area is developed almost to capacity. The recent wildfires were a disquieting reminder that the wholesale real estate development in the region makes it especially vulnerable to natural disasters.

As a result, San Diego firms are starting to look for cheaper locations. IDEC Pharmaceuticals recently opened a manufacturing centre 32 kilometres north of San Diego in the city of Carlsbad (but now that it has merged with Biogen, it will move its headquarters to Massachusetts), and CancerVax is relocating its manufacturing to a Los Angeles suburb.

California officials, meanwhile, are mired in a state budget deficit of at least $\$ 10$ billion, which could double or even triple by the middle of 2004. The state's newly elected governor, Arnold Schwarzenegger, hopes to sell bonds to plug the growing hole in the budget, but the legality of such a move is under question in the courts.

Despite the uncertainties, technology leaders in San Diego say that they are optimistic about the future. Local economic forecasters expect the region's population to grow from 2.8 million in 2000 to 3.6 million in 2020. Industry chiefs note that San Diego has grown steadily in the past 15 years by focusing on education, cross-discipline training and a cooperative business atmosphere. Although they admit that the technology cluster won't continue to grow forever, they believe that they can adapt to economic changes, natural disasters and population growth.

"We've lived with earthquakes and other disasters and people still come to California," says Joseph Panetta, executive director of BIOCOM. "We have to continue to maintain a business climate in San Diego that will allow us to continue to attract people." Eric Niiler is a correspondent for KPBS radio in San Diego.

\section{Profit and pitfalls: building a biotech hub}

Biotechnology is now one of the prime points of focus for US regions that want to develop their local economies. In 2002 it was listed as one of the top two priorities by $83 \%$ of state and local economic-development agencies, according to a survey by the Brookings Institution. Forty-one states currently have biotech development programmes.

"Ten years ago, everyone wanted to be the next Silicon Valley; three or four years ago everyone wanted to be the centre of electronic commerce; now everyone in the economicdevelopment community has zeroed in on biotechnology," says Joseph Cortright, an economist at Impresa, a research-analysis firm in Portland, Oregon. "That says a lot more about the herd instinct of the economic-development fraternity that it does about the economic potential and realities of biotechnology."

The problem is that biotech takes decades to develop, Cortright says, and it needs a healthy supply of venture capital to take it from research to commercialization. "If you have half-a-billion dollars, it's possible to start a research institution, but it's much more difficult, and less likely, that you will spawn a biotechnology industry as a result," he explains.

So does a region go about creating its own biotech hub? Sceptics say that it requires not just a few big-name companies or research institutions, but a critical mass of talent and money. Bringing all of these elements together is no easy task.

Florida and South Dakota are two states that are doing their best to attract the necessary components. In late October, Florida officials approved a \$510-million package to set up a campus for the Scripps Research Institute in Palm Beach County. Based in San Diego, Scripps has an excellent record of producing spin-off companies that Florida is keen to capitalize on.

South Dakota, meanwhile, has successfully attracted biotech company Hematech, currently based in Westport, Connecticut. The company, which generates human antibodies in cattle, took advantage of the state's offer to cover half of the $\$ 15$-million costs of building a research facility in Sioux Falls.

Such moves may be helped by the rising cost of doing business in established clusters such as San Diego or the San Francisco Bay Area. "Within corporate boardrooms, there's a trend towards smaller, more manageable, less costly locations," says John Boyd, president of corporate-relocation firm the Boyd Company, based in Princeton, New Jersey.

Boyd notes that companies also follow money. "Venture-capital firms are now being more selective about who they will fund," he says. "They would be more likely to fund a start-up in South Dakota than in San Diego because of the cost structure."

This evolution is making working conditions more flexible for prospective employees, notes John McCamant, editor of the Medical Technology Stock Letter, a weekly guide focusing on bioscience. "The biotech industry is big enough now and has a lot of people who can now work where they want," he says.

As an investment adviser, McCamant says that he often looks to the out-of-the-way places to find undervalued companies to invest in. $\mathrm{He}$ believes that biotechnology clusters could spring up just about anywhere with the help of 'tech angels', which provide unexpected assistance to start-up firms. "Most get started with angels, friends and family, and there are millionaires all over the place," he says. 